AGRO EKONOMI, Vol 29, Issue 2, December 2018, Page. 196-206

DOI : http://doi.org/10.22146/ae.34339

ISSN 0215-8787 (print), ISSN 2541-1616 (online)

Available at https://jurnal.ugm.ac.id/jae/

\title{
TECHNICAL EFFICIENCY OF SMALLHOLDERS OF OIL PALM CULTIVATION IN OGAN KOMERING ILIR
}

\section{Efisiensi Teknis Perkebunan Kelapa Sawit Rakyat di Ogan Komering Ilir}

\author{
Armina Fariani ${ }^{1}$, Jamhari ${ }^{2}$, Any Suryantini ${ }^{3}$ \\ ${ }^{1}$ Master Student of Agricultural Economics, Faculty of Agriculture, \\ Universitas Gadjah Mada \\ ${ }^{2,3}$ Faculty of Agriculture, Univesitas Gadjah Mada \\ Jalan Flora No.1 Bulaksumur, Yogyakarta, \\ Arminafariani.23@gmail.com
}

Submitted: 27 March 2018; Revised: 20 April 2018; Accepted: 24 September 2018

\begin{abstract}
This study aims to (1) identify the factors affecting the production of oil palm cultivation business by the smallholders and (2) identify the technical level as well as factors influencing business inefficiency of oil palm cultivation by the smallholders in Air Sugihan Sub District of Ogan Komering Ilir Regency, South Sumatera Province. This research uses the basic method of analytical descriptive method. The data were collected by way of observation and direct interviews in the field guided by a questionnaire. The research location was determined purposively, that is in Pangkalan Damai Village, Air Sugihan Sub-district, Ogan Komering Ilir Municipality, South Sumatera Province. Sampling was conducted using non probabilistic sampling method (purposive sampling). The research investigated 79 smallholder farmers of oil palm cultivation in Pangkalan Damai village of Air Sugihan Sub-district, Ogan Komering Ilir Municipality, South Sumatera Province.. On the basis of the analysis, it is revealed that (1) the factors affecting the increase of palm production were labor, land area, TSP fertilizer, NPK fertilizer, organic fertilizer, herbicides and insecticides which also have an effect on decreasing palm production. (2) Palm plantation business was technically efficient with the average technical level of smallholder palm farmers in Air Sugihan Sub-district of Ogan Komering Ilir Municipality of 0.86090. Factors that decrease the technical inefficiency in smallholder palm cultivation in Air Sugihan Sub-district of Ogan Komering Ilir Regency were farmers' education level. This information can be used by the goverment to improve technical efficiency through education in the form of counseling and training to increase production.
\end{abstract}

Keywords: inefficiency, palm, stochastic frontier, technical efficiency

Fariani, A., Jamhari, \&Suryantini, A. (2018) Technical Efficiency Of Smallholders of Oil Palm Cultivation in Ogan Komering Ilir. Agro Ekonomi, 29(2) : 196-206

\section{INTISARI}

Penelitian ini bertujuan (1) mengetahui faktor yang mempengaruhi produksi usaha perkebunan kelapa sawit rakyat dan (2) mengetahui tingkat efisiensi teknis serta faktor yang mempengaruhi inefisiensi usaha perkebunan kelapa sawit rakyat di Kecamatan Air Sugihan Kabupaten Ogan Komering Ilir Provinsi Sumatera Selatan. Metode dasar yang digunakan 
pada penelitian ini adalah metode deskriptif analitis. Data penelitian ini bersumber dari hasil pengamatan dan wawancara secara langsung di lapangan yang dipandu dengan kuisioner. Lokasi penelitian ditentukan secara purposive, yaitu di di Desa Pangkalan Damai Kecamatan Air Sugihan Kabupaten Ogan Komering Ilir Provinsi Sumatera Selatan. Pengambilan sampel dilaksanakan menggunakan metode non probabilistic sampling (purposive sampling). Sampel pada penelitian ini adalah petani rakyat kelapa sawit di desa Pangkalan Damai kecamatan Air Sugihan kabupaten Ogan Komering Ilir Provinsi Sumatera Selatan. Sampel yang diteliti berjumlah 79 petani. Hasil analisis menunjukkan bahwa (1) faktor yang berpengaruh meningkatkan produksi kelapa sawit adalah adalah tenaga kerja, luas lahan, pupuk TSP, pupuk NPK, pupuk organic, herbisida sedangkan insektisida berpengaruh menurunkan produksi kelapa sawit, (2) Usaha perkebunan kelapa sawit sudah efisien secara teknis dengan rata-rata tingkat efisiensi teknis petani kelapa sawit rakyat di Kecamatan Air Sugihan Kabupaten Ogan Komering Ilir adalah sebesar 0.8609. Faktor yang menurunkan inefisiensi teknis pada usaha perkebunan kelapa sawit rakyat di Kecamatan Air Sugihan Kabupaten Ogan Komering Ilir adalah tingkat Pendidikan petani. Hal tersebut dapat dimanfaatkan bagi pemerintah untuk meningkatkan efisiensi teknis melalui pendidikan yang berupa penyuluhan dan pelatihan untuk meningkatkan produksi.

Kata kunci: efisiensi teknis, inefisiensi, kelapa sawit, stochastic frontier

\section{INTRODUCTION}

Palm is listed in the Master Plan for Acceleration and Expansion of Indonesia Economic Development (MP3EI) as one of agricultural potential commodities (Alwarritzi et al., 2015). Oil palm production is the main thing on oil palm plantation. Hence, factors to affect its production require special attention in order to efficiently increase production. According to (Septianita, 2009), the factors of production really determine the size of the production obtained. Thus, the experience related to land production, labor, modal (seed, fertilizer and pesticide) factors are important production factors. Important factors affecting production include land, labor and capital. Beside the production increase, efficiency of oil palm plantation is also an important thing to note. According to (Ridho et al., 2014), the factors that influence the level of efficiency of oil palm production are farmers' age, business experience, and age of oil palm.

The restriction on the use of oil palm land in Indonesia requires farmers to efficiently use the resources. As (Hoffmann et al., 2017), puts it, in the future, the Oil Palm industry will face socio-economic pressures due to land constraints, the volatility of CPO prices, the availability and cost of labor, and the cost of fertilizing. Therefore, it will be a challenge at stake to improve efficiency of resources used.

Ogan Komering Ilir Regency (OKI) is the second largest cultivation area and the second biggest producer of oil palm in South Sumatera with an area of 84.734 hectares and 382.163 tons of fresh fruit bunch (FFB) (Agency, 2017). 
Inputs efficiency on smallholder oil palm plantation in Air Sugihan Sub-district of Ogan Komering Ilir Municipality of South Sumatera province relies on farmers as the field managers. As stated by (Salmiyati et al., 2014), the management of oil palm plantations should include many criteria implemented by the field manager. If plantations are regulated under plant regulations and growthrequirements, the productivity of fresh fruit bunches of palm will surely increase. Some of the requirements to meet for production enhancement consist of land selection, planting materials, technical management, harvesting and the surrounding environment. If all categories of palm plantations are managed and well-integrated to each other, there will be large and appropriate production derived from the fresh fruit bunches of palm.

There have been many previous researches on the technical efficiency of oil palm, but a research on the technical efficiency of oil palm in peatlands in OKI Regency has never been studied previously. In terms of technical efficiency at the farm level, this study particularly aims (1) to identify the factors affecting the production of oil palm plantation business by smallholders and (2) to identify the level of technical efficiency as well as its influence on the business inefficiency of oil palm plantation by smallholders in Air Sugihan sub disrict of Ogan Komering Ilir Regency, South Sumatera Province.

\section{METHODS}

The basic method used in this research was analytical descriptive method. The data were derived from direct observation and field interviews conducted in August September 2017 guided by questionnaire. The data were to be part of a research entitled "Mata Pencaharian Masyarakat di Lahan Gambut" as a form of cooperation between Faculty of Agriculture UGM and Peat Restoration Agency (BRG). The data of oil palm smallholder business referred to the data for the period of 1 year i.e. from August 2016 - July 2017. The research location was determined purposively in OKI district.

Sampling was conducted in August of 2017, using non probabilistic sampling method. To determine the number of samples, the researcher used the Slovin formula:

$\mathrm{n}=\frac{N}{\left(N E^{2}+1\right)}$

$\mathrm{n}=\frac{390}{\left(390\left(0,1^{2}\right)+1\right)}=79$

where :

$\mathrm{n}=$ sample size

$\mathrm{N}=$ population size

$\mathrm{E}=$ neglected errors $($ tolerance limit $=10 \%)$

This research investigated the oil palm smallholder farmers in Pangkalan Damai village of Air Sugihan district of Ogan Komering Ilir, South Sumatera Province with the average business life of at least 10 years. 
To know the factors affecting production of oil palm, the researcher used stochastic production function equation to be estimated with Maximum Likelihood Estimation (MLE) method. The tests were performed using the program Frontier 4.1. (Coelli et al., 2005). The equations to be tested are as follows:

$\operatorname{Ln} Y=\beta_{0}+\beta_{1} \ln X_{1}+\beta_{2} \ln X_{2}+\beta_{3} \ln$ $X_{3}+\beta_{4} \ln X_{4}+\beta_{5} \ln X_{5}+\beta_{6} \ln X_{6}+\beta_{7} \ln$ $X_{7}+\beta_{8} \ln X_{8}+\beta_{9} \ln X_{9}+\beta_{10} \ln X_{10}+\beta_{11} \ln$ $\mathrm{X}_{11}+\beta_{12} \ln \mathrm{X}_{12}+\beta_{13} \mathrm{D}_{1}+(\mathrm{Vi}-\mathrm{Ui})$

$\mathrm{Y}$ is the production of oil palm produced by oil palm smallholder farmers' respondent in the research area. Factors that are suspected to affect the oil palm production are amount of labor (X1), land area (X2), amount of Urea fertilizer (X3), amount of TSP fertilizer (X4), amount of KCL fertilizer (X5), amount of NPK (X6), amount of organic fertilizer (X7), amount of dolomite fertilizer (X8), amount of herbicide (X9), amount of insecticide (X10), amount of rodenticide (X11), plant age (X12), farmer age (X13) and variable of oil palm varieties (D1), which are categorized as tenera varieties (1) and varieties other than tenera $(0)$. There are two other variables, in addition to the variables described above, i.e. errors caused by uncontrollable factors (Vi), and errors triggered by controllable factors (Ui).

The Frontier 4.1 program will lead to technical efficiency of oil palm farming with the following formula:
$\mathrm{TEi}=\frac{Y i}{Y i *}=\frac{E(Y i \mid U i, X i)}{E(Y t \mid U i=0, X i)}=E\left[\frac{\exp (-U i)}{s i}\right]$

Note :

TEi : Technical efficiency of farmer i

Yi : Potential production $\mathrm{Yi}^{*}$ : Actual production

The value of TEi ranges from 0 to 1 . The value of TE that is closer to 1 means that a farm is technically efficient. If the value of TEi is closer to 0 , it means that the farming system is technically inefficient.

To calculate the value of Ui effect (technical inefficiency) this research used factor analysis approach that affects the technical inefficiency of farmers. Factors that are expected affect the level of oil palm smallholder farmer's technical inefficiency are farmers' age, farmers' education level, farming experience and number of family members.

Mathematically, technical inefficiency $(\mathrm{U})$ is formulated as follows:

$$
\mathrm{Ui}=\delta_{0}+\delta_{1} \mathrm{Z}_{1}+\delta_{2} \mathrm{Z}_{2}+\delta_{3} \mathrm{Z}_{3}+\delta_{4} \mathrm{Z}_{4}
$$

Where :

Ui $=$ Technical inefficiency score

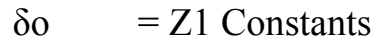

$\mathrm{d}_{1}-\mathrm{d}_{4}=$ dummy coefficients

$\mathrm{Z}_{1} \quad=$ Age of farmers (year)

$\mathrm{Z}_{2} \quad$ = Farmers' education level (year)

$\mathrm{Z}_{3} \quad=$ Experience in farming (year)

$\mathrm{Z}_{4} \quad=$ Family Contribution (People) 


\section{RESULTS AND DISCUSSION}

The results show that the average of oil palm production is $36.984 \mathrm{~kg} /$ year, with the average production per hectare of $17.599 \mathrm{~kg} / \mathrm{ha}$. The production of Oil Palm may be influenced by selected oil palm varieties and the age of oil palm crops. The average of land use in the research area is 2.1 ha, and the most extensive land use is 8 ha and the least land use was 0.4 ha. The average age of the plant is at the age of 9.98 years, which is based on the age of the plant included in the mature plant category (MP). Types of fertilizer used include Urea, TSP, KCL, NPK, organic fertilizer and dolomite. To overcome weeds and pest attacks, farmers use herbicides, insecticides, and rodenticides. The labor outpouring is empowered on fertilizing activities, weeding, spraying pests and diseases, harvesting as well as transporting crops. Harvesting and transporting crops consume the most labor because of the 24 time per year harvesting frequency. The production input of oil palm plantation business used in the research location can be seen in Table 1.

Table 2. covers an estimation analysis of stochastic frontier production function, the sigma-squared value of 0.165033 that is significant to the 95 percent confidence level and is normally distributed because it is small or close to zero. Thus, it is conclusive that the diversity of oil palm production contributed by inefficiency effect and external effect has real variations. The value of gamma $(\gamma)$ can be interpreted that 42.67 percent of oil palm production variation among respondent farmers observed is caused by efficiency difference and the remaining 57.33 percent is caused by an external factor (noise). This is also indicated by the result of the generalizedlikelihood (LR) of stochastic frontier

Table 1. Average Use of Production Factors in Air Sugihan Subdistrict, Ogan Komering Ilir Regency

\begin{tabular}{lcrr}
\hline \multirow{2}{*}{ Production Factor } & \multirow{2}{*}{ Unit } & \multicolumn{2}{c}{ Amount of Usage } \\
\cline { 3 - 4 } & & 280.22 & Per Farm \\
MP Palm Oil & Tree & 68.09 & 133.72 \\
Labor & Man-hours & 1.52 & 32.49 \\
Organic fertilizer & $\mathrm{Lt}$ & 270.25 & 0.72 \\
Urea Fertilizer & $\mathrm{Kg}$ & 334.81 & 128.96 \\
NPK fertilizer & $\mathrm{Kg}$ & 3.164 & 159.77 \\
KCL fertilizer & $\mathrm{Kg}$ & 189.87 & 1.51 \\
TSP fertilizer & $\mathrm{Kg}$ & 180.70 & 90.61 \\
Dolomite & $\mathrm{Kg}$ & 11.07 & 86.23 \\
Herbicide & $\mathrm{Lt}$ & 2.43 & 5.28 \\
Rodenticides & $\mathrm{Lt}$ & 7.73 & 1.16 \\
Insecticide & $\mathrm{Lt}$ & & 3.69 \\
\hline
\end{tabular}

Source. Primary Data Analysis, 2017 
Table 2. Estimation of Stochastic Frontier Production Function

\begin{tabular}{|c|c|c|c|c|}
\hline Variables & Parameter & Coefficient & & t ratio \\
\hline Ln Constants & $\beta 0$ & 9.394027 & $* * *$ & 21.00790 \\
\hline Ln Labor $\left(\mathrm{X}_{1}\right)$ & $\beta 1$ & 0.132179 & $*$ & 1.44280 \\
\hline Ln Land Area $\left(\mathrm{X}_{2}\right)$ & $\beta 2$ & 0.827649 & $* * *$ & 8.09885 \\
\hline Ln Amount of Urea $\left(\mathrm{X}_{3}\right)$ & $\beta 3$ & 0.006292 & Ns & 1.10998 \\
\hline Ln Amount of TSP $\left(X_{4}\right)$ & $\beta 4$ & 0.010134 & $* *$ & 1.99599 \\
\hline Ln Amount of KCL $\left(\mathrm{X}_{5}\right)$ & $\beta 5$ & 0.008975 & Ns & 0.56146 \\
\hline Ln Amount of NPK $\left(X_{6}\right)$ & $\beta 6$ & 0.013150 & $* *$ & 2.31570 \\
\hline Ln Amount of Organic $\left(\mathrm{X}_{7}\right)$ & $\beta 7$ & 0.025775 & $*$ & 1.62202 \\
\hline Ln Amount Dolomite $\left(\mathrm{X}_{8}\right)$ & $\beta 8$ & 0.003798 & Ns & 0.64402 \\
\hline Ln Amount of Herbicides $\left(\mathrm{X}_{9}\right)$ & $\beta 9$ & 0.011348 & $*$ & 1.42774 \\
\hline Ln Amount of Insecticides $\left(\mathrm{X}_{10}\right)$ & $\beta 10$ & -0.018720 & $* *$ & -1.91789 \\
\hline Ln Amount of Rodenticide $\left(\mathrm{X}_{11}\right)$ & $\beta 11$ & 0.002240 & Ns & 0.25443 \\
\hline Ln Plant Age $\left(\mathrm{X}_{12}\right)$ & $\beta 12$ & 0.125297 & Ns & 0.87968 \\
\hline Varieties $\left(D_{1}\right)$ & $\beta 13$ & 0.011069 & Ns & 0.10473 \\
\hline sigma-squared & & 0.165033 & $* *$ & 2.97424 \\
\hline Gamma & & 0.426795 & $*$ & 1.49124 \\
\hline log likelihood function OLS & & & -28.5819 & \\
\hline log likelihood function MLE & & & -24.4077 & \\
\hline LR test of the one-sided error & & & 8.348456 & \\
\hline
\end{tabular}

Source : Primary Data Analysis, 2017

Note :

$*=$ significant at the confidence level $90 \%(\mathrm{t}$-count $=1.295)$

$* *=$ significant at the confidence level $95 \%(\mathrm{t}$-count $=1.669)$

$* * *=$ significant at the confidence level $99 \%(\mathrm{t}$-count $=2.386)$

$\mathrm{ns}=$ not significant

production function of 8.348 which has a significant effect on the error rate $(\alpha)$ of 2.5 percent or LR value greater than the kodde and plam values at the level of error (a) 2.5 percent that is equal to 7.257 with restriction value equal to 6 .

The estimation results of the stochastic frontier production function with the MLE method indicate that the variables that have a significant and positive effect on the 90 percent confidence level on frontier production are labor variables, organic fertilizer variables, and herbicide variables.
Variables that have a significant and positive effect on the 95 percent confidence level are TSP fertilizer variables, NPK fertilizer variables, while insecticides have significant and negative variables at a 95 percent confidence level. The variable land area has a significant and positive effect at a 99 percent confidence level.

Each 1 percent increase of the labor force will increase palm production by 0.13218 percent. Production factors in the form of labor are a high elasticity factor of production. The average use of labor 
at the research location is 68 Man-hours/ year, where most of the workforce comes from the family workforce. This is in line with the research conducted by (Alfayanti \& Efendi, 2013), highlighting the fact that labor affects production of smallholder palm plantation in Mukomuko Regency.

Each increase of 1 percent of land area can upgrade FFB production of 0.8524 perceent. Land area variable is more responsive than other variables because it has the greatest coefficient. Thus, if the farmers want to increase the production of their oil palm plantation, the area of land should be the main concern, which is in accordance with that revealed by (Septianita, 2009), i.e. oil palm area in Makartitama Village OKU.

Increasing use of TSP fertilizer by 1 percent leads to an upgrade of FFB production by 0.0144 percent. At the study site, only $44.30 \%$ of sample farmers used TSP fertilizer. TSP fertilizer is useful for increasing nutrients in the soil that is poor in phosphate nutrients (Purba et al., 2017).

An increase in the use of NPK fertilizer by 1 percent can upgrade TBS plantation production of 0.0172 percent. At the research location, farmers who used NPK fertilizer were $74.68 \%$. Result of this study is in line with the research by (Sinulingga et al., 2015) discovering that NPK fertilizer tends to make better growth of plants than those without fertilizer application.
Organic fertilizers are useful for enhancing soil physical, chemical and biological fertility (Hartatik et al., 2015). Each additional use of organic fertilizer of 1 percent at the research location can increase production of fresh palm fruit bunches of 0.0324 percent. This study is in line with the research conducted by (Adnan et al, 2015), which states that application of organic fertilizer can improve soil fertility by supplying energy and body building materials for most micro-organisms.

Weeds will compete with palm oil to seize nutrients and fertilizers, making it difficult for the harvesting process to reduce FFB production. The addition of herbicides to control weeds by 1 percent will increase FFB production by 0.011348 percent. According to (Nufvitarini et al., 2016), herbicides are toxic compounds that are used to kill or control weeds. The use of herbicides is in accordance with SOP that refers to the criteria and principles of sustainable gardens.

The use of insecticides in the research location was 2.97 liters/ha. Based on SOP for oil palm cultivation, the limit of insecticide use is 1 liter/ha. Thus, an increase in insecticide use by 1 percent will reduce FFB production by 0.018720 percent. According to (Syahputra, 2011), insecticides have been used to control insect pests in oil palm plantations. This is in line with the research conducted by (Ardiansyah et al., 2018), that excessive 
use of insecticides will reduce soybean production.

Table 3. on the technical efficiency analysis results of each farmer delineates that the average value of technical efficiency index is achieved by oil palm planters of 0.86090 . The table shows that on average, the palm oil of respondents' farmers has led to high results approaching the maximum level and is technically efficient. In the short term, average oil palm growers only have a chance to increase their production by 10.83 percent $(1-(0.86090 / 0.96555)$

Table 3. Distribution of Technical Efficiency Level of Palm Oil Plantation

\begin{tabular}{lrr}
\hline $\begin{array}{c}\text { The distribution } \\
\text { of index }\end{array}$ & $\begin{array}{c}\text { Number of } \\
\text { farmers }\end{array}$ & \multicolumn{1}{c}{$\%$} \\
\hline$<=0,60$ & 1 & 1.27 \\
$0.61-0.70$ & 6 & 7.59 \\
$0.71-0.80$ & 7 & 8.86 \\
$0.81-0.90$ & 38 & 48.10 \\
$0.91-1.00$ & 27 & 34.18 \\
\hline Total & \multicolumn{3}{c}{100.00} \\
\hline Mean & 0.86090 \\
\hline Minimum & 0.32197 \\
\hline Maximum & 0.96555 \\
\hline Source $:$ Primary Data Analysis, 2017
\end{tabular}

Source : Primary Data Analysis, 2017 by applying the most efficient inputs of production. Since the majority of oil palm smallholders are technically efficient, the priority of farmers is not to increase the number of production factors that have a significant effect on oil palm production, but to look at managerial and socioeconomic factors as sources of inefficiency.

Education level in the inefficiency index with a coefficient of value -0.1687632 means that the higher it is, the lower oil palm smallholder technical inefficiency index. In other words, the level of education can reduce the technical inefficiency of oil palm plantation businesses. Education influences oil palm farmers in making decisions in conducting their farming. This is in line with the research owned by (Rizka et al., 2014), education can be an important factor in shaping the mindset and decision-making process of undertaking the business. This result is in accordance with the research carried out in Western Kenya, where education can reduce technical inefficiency in maize farming. This study was conducted by (Essilfie et al., 2011)

Table 4. The Estimation Factors which Affect the Technical Inefficiency

\begin{tabular}{lcccc}
\hline Variable & Parameter & Coefficient & & t ratio \\
\hline Farmers'Age & $\mathrm{Z}_{1}$ & -0.0127246 & $\mathrm{Ns}$ & -1.0737 \\
Education Level & $\mathrm{Z}_{2}$ & -0.1687632 & $* *$ & -2.2666 \\
Experience in Farming & $\mathrm{Z}_{3}$ & -3.0329504 & $\mathrm{Ns}$ & -0.8459 \\
Family Contribution & $\mathrm{Z}_{4}$ & -0.1767959 & $\mathrm{Ns}$ & -1.1991 \\
\hline
\end{tabular}

Source: Primary Data Analysis, 2017

Where:

$*=$ Significant at $90 \%$ confidence level $(t$ count $=1.295)$

$* *=$ Significant at $95 \%$ confidence level $(\mathrm{t}$ count $=1.669)$

$* * *=$ Significant at $99 \%$ confidence level $(\mathrm{t}$ count $=2.386)$ 


\section{CONCLUSION AND SUGGESTION}

Factors that affect the increase of smallholder oil palm plantation production in Air Sugihan Sub-Regency of Ogan Komering Ilir Regency are labor, land area, TSP fertilizer, NPK fertilizer, organic fertilizer, herbicides and insectides which has an effect on decresing palm production.

Oil palm plantations are proven to be technically efficient with the average technical efficiency of smallholder oil palm plantations in Air Sugihan Sub-Regency of Ogan Komering Ilir Regency of 0.86090 . Factors that have an effect on decreasing technical inefficiency in smallholder oil palm plantation in Air Sugihan SubRegency of Ogan Komering Ilir Regency is education level.

It is unveiled that education has a significant effect on reducing the level of technical inefficiency. Thus, it is expected that the government improve technical efficiency through education. The education provided can be in the form of counseling for farmers. In order to improve the technical efficiency of the palm oil plantation business in Pangkalan Damai Village, Air Sugihan Sub-district of Ogan Komering Ilir Regency, South Sumatra Province, it is necessary to conduct counseling and training so that farmers can have better understanding to the technology of oil palm cultivation and able to adopt the technology in order to take care of their smallholder. All this time, counselling is only done for once at the beginning of the smallholder opening by the government.

\section{ACKNOWLEDGE}

The author would like to thank the Peat Restoration Agency (BRG) for funding in this research.

\section{REFERENCES}

Adnan, I. S., Utoyo, B., \& Kusumastuti, A. (2015). Pengaruh Pupuk NPK dan Pupuk Organik terhadap Pertumbuhan Bibit Kelapa Sawit (Elaeis guineensis Jacq.) di Main Nursery. Jurnal Agro Industri Perkebunan, 3(2), 69-81.

Agency, C. S. (2017). Sumatera Selatan Province In Figure 2017.

Alfayanti, \& Efendi, Z. (2013). Analisis Faktor - Fakktor yang Mempengaruhi Produksi Kelapa Sawit Rakyat di Kabupaten Mukomuko. AGRISEP, 13(1), 1-10.

Alwarritzi, W., Nanseki, T., \& Chomei, Y. (2015). Analysis of The Factors Influencing The Technical Efficiency Among Oil Palm Smallholder Farmers in Indonesia. Procedia Environmental Sciences, 28(SustaiN 2014), 630-638. https://doi. org/10.1016/j.proenv.2015.07.074 
Ardiansyah, N., Hartono, S., \& Suryantini, A. (2018). Technical Efficiency of Soybean in Pandeglang Regency. Agro Ekonomi, 29(1), 1-17.

Coelli, T. J., Rao, D. S. P., O’Donnell, C. J., \& Battese, G. E. (2005). An Introduction to Efficiency and Productivity Analysis, Second Edition (2nd ed.). Springer US. https://doi. org/10.1007/b136381

Essilfie, F. L., Asiamah, M. T., \& Nimoh, F. (2011). Estimation of Farm Level Technical Efficiency in Small Scale Maize Production in The Mfantseman Municipality in The Central Region of Ghana: A Stochastic Frontier Approach. Journal of Development and Agricultural Economics, 3(14), 645-654. https://doi.org/10.5897/ JDAE11.069

Hartatik, W., Husnain, \& Widowati, L. R. (2015). Peranan Pupuk Organik dalam Peningkatan Produktivitas Tanah dan Tanaman. Jurnal Sumberdaya Lahan, Vol 9 No 2, 107-120.

Hoffmann, M. P., Donough, C. R., Cook, S. E., Fisher, M. J., Lim, C. H., Lim, Y. L., ... Oberthür, T. (2017). Yield Gap Analysis in Oil Palm : Framework Development and Application in Commercial Operations in Southeast Asia. Agricultural Systems, 151,
12-19. https://doi.org/10.1016/j. agsy.2016.11.005

Nufvitarini, W., Zaman, S., \& Junaedi, A. (2016). Pengelolaan Gulma Kelapa Sawit (Elaeis guineensis Jacq.) Studi Kasus di Kalimantan Selatan. Buletin Agrohorti, 4(1), 29-36.

Purba, S. T. Z., Damanik, M., \& Lubis, K. S. (2017). Dampak Pemberian Pupuk TSP dan Pupuk Kandang Ayam Terhadap Ketersediaan dan Serapan Fosfor Serta Pertumbuhan Tanaman Jagung Pada Tanah Inceptisol Kwala Bekala. Jurnal Agroekoteknologi FP USU, 5(3), 638-643.

Ridho, Z., Hadi, S., \& Yusri, J. (2014). Efisiensi Produksi Kelapa Sawit Pola Swadaya di Desa Senama Nenek Kec Tapung Hulu Kabupaten Kampar. JOM Faperta Unri, 1.

Rizka, E., Sakti, H., \& Arifudin. (2014). Faktor-Faktor Yang Mempengaruhi Minat Petani Kelapa Sawit Rakyat Berpartisipasi Dalam Sertifikasi Produk Di Kabupaten Kampar. SEPA, 11(1), 142-150.

Salmiyati, S., Heryansyah, A., Idayu, I., \& Supriyanto, E. (2014). Oil Palm Plantations Management Effects on Productivity Fresh Fruit Bunch ( FFB ). APCBEE Procedia, 8, 
282-286. https://doi.org/10.1016/j. apcbee.2014.03.041

Septianita. (2009). Faktor-Faktor yang Mempengaruhi Produksi Kelapa Sawit (Elaeis quinensis Jack) dan Kontribusinya Terhadap Pendapatan Keluarga di Desa Makartitama Kec. Peninjauan Kab. OKU. Agronobis, 1(2), 78-85.

Sinulingga, E. S. R., Ginting, J., \& Sabrina, T. (2015). Pengaruh Pemberian
Pupuk Hayati Cair dan Pupuk NPK Terhadap Pertumbuhan Bibit Kelapa Sawit di Pre Nursery. Jurnal Online Agroekoteknologi, 3(3), 1219-1225.

Syahputra, E. (2011). Aktivitas dan Keefektifan Insektisida Berbahan Aktif Majemuk Thiodicarb dan Triflumuron Terhadap Hama Ulat Kantong Metisa Plana Pada Tanaman Kelapa Sawit. Jurnal Perkebunan Dan Lahan Tropika, 1(2), 1-8. 